\title{
Development of Vegetation Communities in a Retrogressive Thaw Slump near Mayo, Yukon Territory: A 10-Year Assessment
}

\author{
A-P. BARTLEMAN, ${ }^{1}$ K. MIYANISHI, ${ }^{2}$ C.R. BURN ${ }^{3,4}$ and M.M. CÔTÉ ${ }^{3}$
}

(Received 14 December 1998; accepted in revised form 19 September 2000)

\begin{abstract}
The vegetation in a retrogressive thaw slump, first surveyed and documented in 1987, was revisited 10 years later to investigate its subsequent development and to test a chronosequence-based successional model. The thaw slump stabilized in 1994, when the headwall became covered by organic and mineral debris. As a result, the meltwater supply from headwall ablation ceased. Alteration of environmental conditions due to stabilization of the headwall diverted the vegetation succession from the chronosequence determined in 1987. Areas that were marshy in 1987 dried up, and an area dominated by Polygonum alaskanum appeared close to the headwall. Much of the thaw slump was dominated by Salix spp. in 1997, rather than the Equisteum of 1987. However, the ground more than $200 \mathrm{~m}$ from the headwall, over a decade old in 1987, experienced less change in edaphic conditions, and the communities there continued to develop a structure approaching the surrounding undisturbed forest.
\end{abstract}

Key words: permafrost, retrogressive thaw slump, vegetation succession, Yukon Territory

RÉSUMÉ. La végétation située dans un décrochement de fonte régressif, étudiée et documentée pour la première fois en 1987, a fait l'objet d'une autre étude sur place dix ans plus tard pour examiner son évolution et tester un modèle de succession fondé sur la chronoséquence. Le décrochement de fonte s'est stabilisé en 1994, quand le mur de rimaye s'est couvert de débris organiques et minéraux. Il en a résulté que l'alimentation en eau de fonte venant de l'ablation du mur de rimaye a cessé. Le changement dans les conditions environnementales dû à la stabilisation du mur a détourné la succession végétale de la chronoséquence établie en 1987. Des zones qui étaient marécageuses en 1987 se sont asséchées, et une étendue où dominait Polygonum alaskanum est apparue près du mur. En 1997, une grande partie de la zone du décrochement de fonte était dominée par des espèces Salix, plutôt qu'Equisteum, comme c'était le cas en 1987. Toutefois, le sol situé à plus de $200 \mathrm{~m}$ du mur de rimaye, sol vieux de dix ans en 1987, a subi moins de changement dans les conditions édaphiques, et les communautés y ont continué à évoluer vers une structure qui se rapproche de la forêt non perturbée située à la périphérie.

Mots clés: pergélisol, décrochement de fonte régressif, succession végétale, Territoire du Yukon

Traduit pour la revue Arctic par Nésida Loyer.

\section{INTRODUCTION}

Retrogressive thaw slumps are characteristic geomorphological features of northern permafrost terrain. They are composed of a relatively steep $\left(20^{\circ}-90^{\circ}\right)$ headwall of ice-rich permafrost and a more gentle $\left(3^{\circ}-10^{\circ}\right)$ foot slope of thawed material (Burn and Lewkowicz, 1990; Fig. 1). As permafrost in the headwall melts, soil falls onto the foot slope, producing a bare soil surface that can subsequently be colonized by plants ab initio or from residual clumps of vegetation that have survived the descent to the foot slope. A chronosequence of vegetation development may be defined on the foot slope if the time since initiation of revegetation can be determined from aerial photographs and field surveys.

In 1987, Burn and Friele (1989) documented the vegetation pattern at a retrogressive thaw slump that had been initiated in 1949 near Mayo, Yukon Territory, Canada. They identified six vegetation units in the thaw slump that were distinct from the vegetation of the surrounding undisturbed forest and hypothesized that these units represented a chronosequence, with those closest to the headwall being the youngest surfaces. Burn and Friele (1989) also examined the vegetation community in a stabilized thaw slump nearby, approximately 43 years after disturbance. They noted that all the important constituents of the undisturbed forest surrounding the thaw slump had become established in the stabilized slump.

The active thaw slump continued to develop until 1994, when the headwall was stabilized by organic debris and mineral sediment covering and insulating the exposed face. Stabilization of the headwall induced a physically significant change in the hydrology of the foot slope, as the meltwater supply was terminated, altering soil moisture conditions.

\footnotetext{
${ }^{1}$ Department of Human Biology and Nutrition, University of Guelph, Guelph, Ontario N1G 2W1, Canada

${ }^{2}$ Department of Geography, University of Guelph, Guelph, Ontario N1G 2W1, Canada

${ }^{3}$ Department of Geography and Environmental Studies, Carleton University, 1125 Colonel By Drive, Ottawa, Ontario K1S 5B6, Canada

${ }^{4}$ Corresponding author: christopher_burn@ carleton.ca

(C) The Arctic Institute of North America
} 

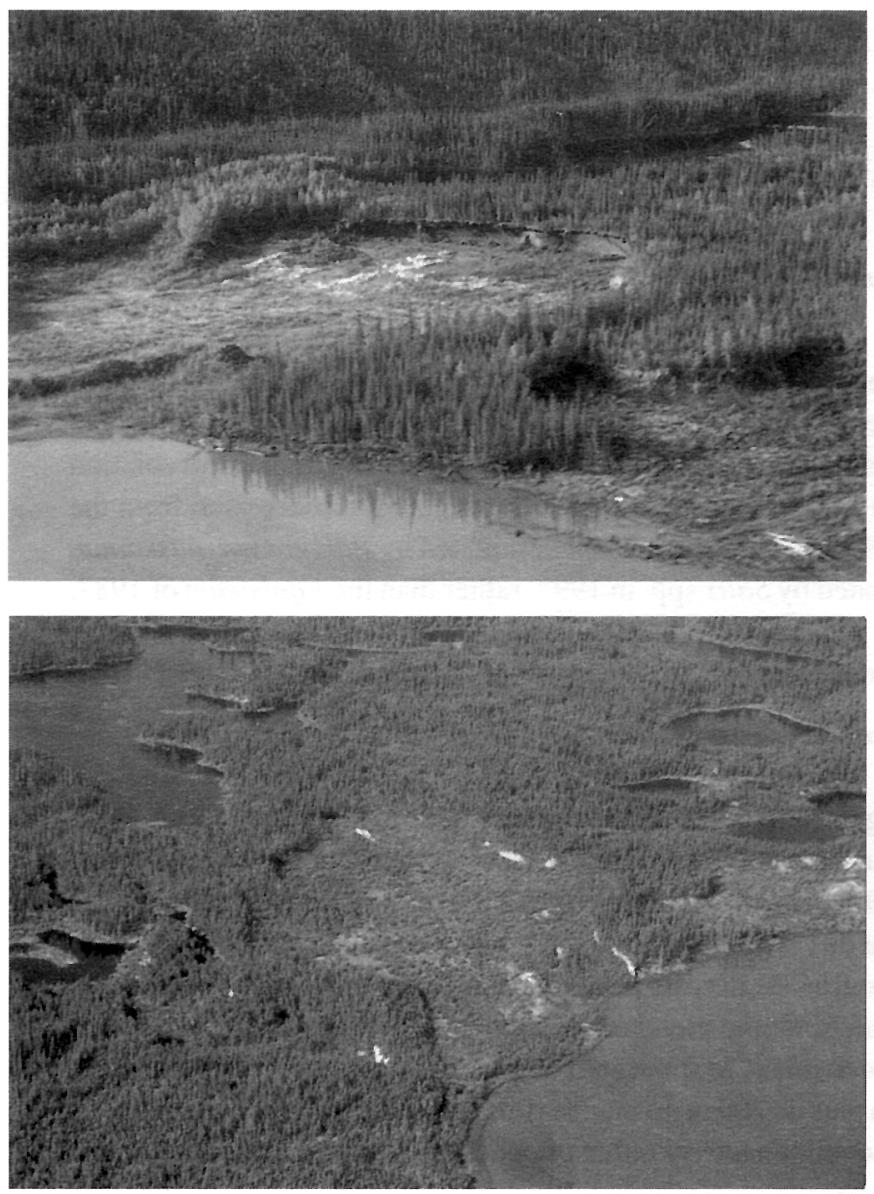

FIG.1. Oblique aerial photographs of a retrogressive thaw slump near Mayo, Yukon Territory: (top) in August 1984, with both headwall and foot slope evident; (bottom) in July 1996, after the thaw slump had stabilized. The long axis of the slump is oriented northeast-southwest, with the Stewart River to the north.

This paper reports a vegetation survey conducted in 1997 to provide a longitudinal examination of the chronosequence-based successional sequence hypothesized by Burn and Friele (1989). While there are considerable data on primary succession in boreal flood plains and tundra environments (e.g., Viereck, 1970; Lambert, 1972; Gill, 1973; Billings and Peterson, 1980; Ovenden, 1986), less is known about sequences developed on disturbances in the ice-rich terrain of the boreal forest. No other published reports of long-term vegetation succession in thaw slumps are known to the authors. Understanding the rate and composition of vegetation sequences during primary succession is of assistance in managing restoration of artificially disturbed sites (e.g., Cargill and Chapin, 1987; Wilson et al., 1996).

\section{STUDY AREA}

Mayo $\left(63^{\circ} 35^{\prime} \mathrm{N} 135^{\circ} 35^{\prime} \mathrm{W} ; 504 \mathrm{~m}\right.$ a.s.1.) is located in the boreal forest of central Yukon Territory and in the widespread discontinuous permafrost zone (Heginbottom et al., 1995). The climate at Mayo is subarctic continental, with a mean annual temperature of $-3.6^{\circ} \mathrm{C}$ and an annual precipitation of $360 \mathrm{~mm}$ (Environment Canada, 1993). The study area is $3 \mathrm{~km}$ upstream from Mayo on the Stewart River, in glaciolacustrine sediments deposited at the end of Late Wisconsinan McConnell glaciation (Bostock, 1966; Hughes, 1983). These sediments are ice-rich, and the area contains several thermokarst lakes (Burn and Smith, 1990). The forest at undisturbed sites in the study area is dominated by white spruce (Picea glauca), with black spruce ( $P$. mariana) and paper birch (Betula papyrifera) also common in the region. The mean annual ground temperature beneath the undisturbed forest presently ranges between $-2.4^{\circ}$ and $-1.4^{\circ} \mathrm{C}$ (Burn, 1998; Smith et al., 1998), and the active layer is between $0.6 \mathrm{~m}$ and $1.0 \mathrm{~m}$ thick (Leverington, 1995).

\section{FIELD METHODS}

Fieldwork was carried out in July and early August 1997 using the same methods as Burn and Friele (1989). Six vegetation units within the slump were visually delineated by their homogeneity, labeled with their dominant species, and mapped by plane table (Fig. 2). The units were mapped without reference to the 1987 survey (Fig. 3). The age of each unit was determined from ground surveys conducted during most summers between 1987 and 1994, and from mappings presented by Burn and Friele (1989). The vegetation communities in the undisturbed forest and stabilized thaw slump were not sampled in 1997, as there had been little distinction between them in 1987, and the focus of the study was the development of vegetation in the

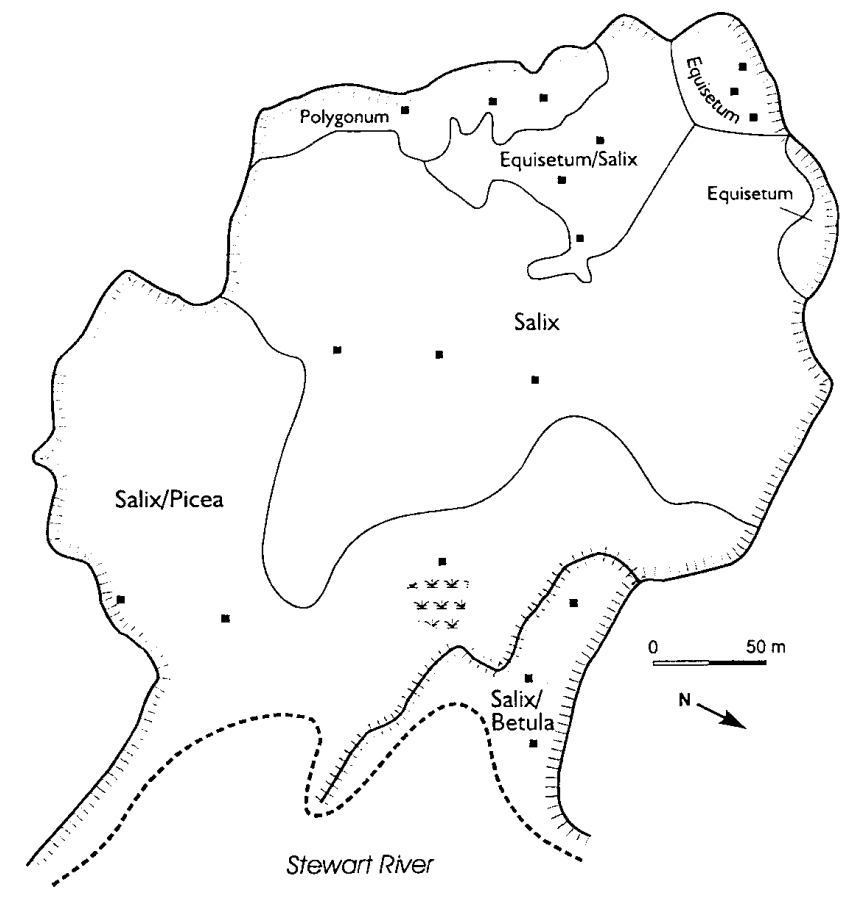

FIG. 2. Vegetation units in the retrogressive thaw slump near Mayo, Yukon Territory, in 1997. The black squares indicate the locations of sampling plots. The water table was at the ground surface in the shaded area. 


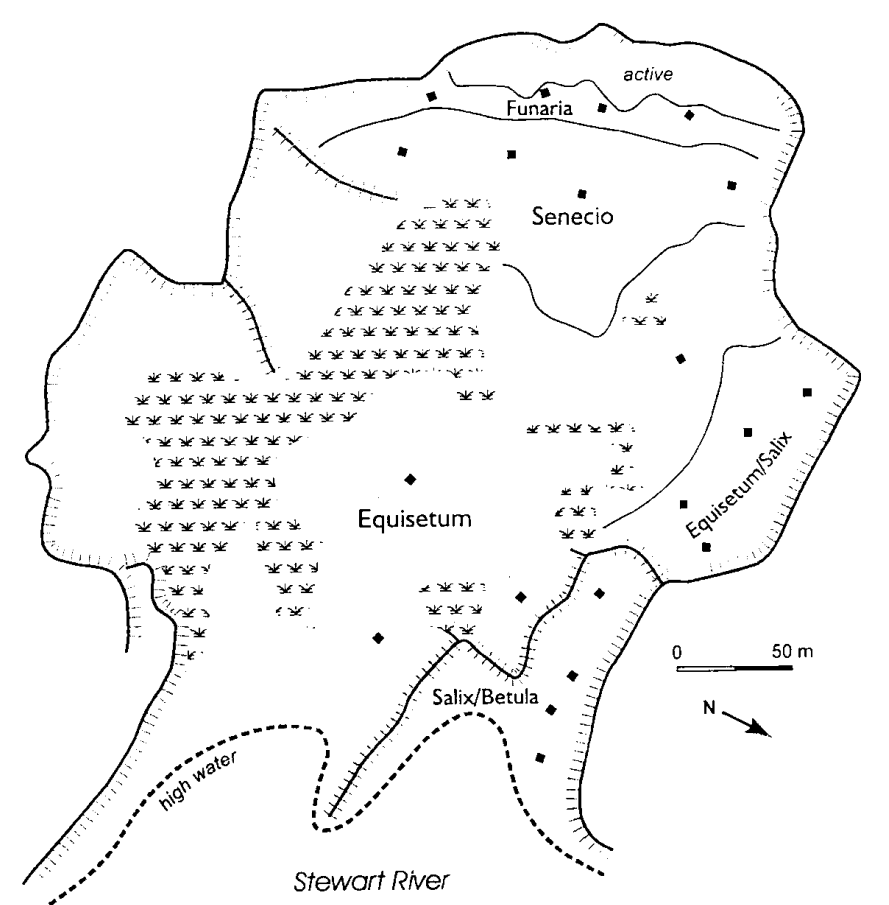

FIG. 3. Vegetation units in the retrogressive thaw slump near Mayo, Yukon Territory, in 1987 (Burn and Friele, 1989, Fig. 6). The black squares indicate the locations of sampling plots. The water table was at the ground surface in the shaded area.

active slump. No forest fires or other major environmental changes had occurred near the thaw slump between 1987 and 1997, and the undisturbed forest community on three sides of the slump was assumed not to have changed.

The nested plot technique was used to determine appropriate plot sizes for describing the species composition and abundance in each unit (Mueller-Dombois and Ellenberg, 1974; see Table 1). Three sampling plots were randomly located within each unit. Within each plot, ground-cover estimates for each species were recorded using the Braun-Blanquet cover-abundance scale (MuellerDombois and Ellenberg, 1974). Data obtained from the three sample plots within each unit were averaged to obtain a single cover-abundance value for each species in the unit. Species nomenclature followed Porsild and Cody (1980) and Cody (1996). Within the unit adjacent to the headwall, remnant islands of vegetation from the undisturbed forest, which had fallen or slid down the headwall, were demarcated and excluded from the sampling plots. These islands covered about $25 \%$ of the area in this unit. Remnant islands could no longer be defined in other units. Table 1 presents the species lists compiled in 1987 and 1997, assembled for comparison, listed by vegetation unit, and grouped by growth form.

\section{Data Analysis}

The structure of statistical variation in the data presented in Table 1 was examined by detrended correspondence analysis (Ter Braak and Prentice, 1988; Ter Braak,
1995). Analyses were conducted separately on data from 1987 and 1997, using a routine described by Benzécri (1992), which was downloaded from the Internet (http:// www.xlstat.com). The Braun-Blanquet cover-abundance data were used directly in the analyses, allocating a value of 0.5 for species with few individuals and 0.1 for species represented by solitary specimens, respectively + and $r$ on the Braun-Blanquet scale. The statistical tests were repeated with data sets from which species that appeared in only one or two units were omitted. The results were not materially different from those obtained with the full sets, which are presented below. Data collected in 1987 included assessment of the vegetation communities in the undisturbed forest and stabilized slump, and these communities are included in the analysis for 1987 (see Burn and Friele, 1989, Table 3). Similar data were not available for 1997, but since these communities appear to have changed little, the data for 1987 from these units were used in the analysis for 1997.

\section{RESULTS}

Vegetation units mapped in 1987 and 1997 are presented in Figures 2 and 3. In 1987, the six units ranged in age from $0-1$ year (active unit) to $12-15$ years (Salix/ Betula unit); in 1997, the unit ages ranged from 4-7 years (Equisetum unit) to 22-25 years (Salix/Betula unit) (Table 1). The sizes of sample plots in the units of age $5-13$ years declined, indicating that the plant cover there had become more uniform over the decade. Characteristics of the vegetation units delineated in 1997 are provided below.

\section{Equisetum (Unit 1: 4-7 Years Old)}

Comparison of Figures 2 and 3 indicates that the area occupied by this unit was part of the undisturbed forest in 1987. The unit was adjacent and parallel to the headwall and was the wettest environment in the slump above the flood plain of the Stewart River, with many puddles. Equisetum arvense was the dominant species, covering $25-50 \%$ of the area. The abundance of Equisetum arvense, the scarcity of most other herbs, and the lack of sub-shrubs were due in part to the moist environment. Only one subshrub (Ribes hudsonianum) was identified, and the lone specimen was less than $10 \mathrm{~cm}$ tall. All Salix colonizers in this unit were $50-60 \mathrm{~cm}$ tall at most.

\section{Polygonum (Unit 2: 5-10 Years Old)}

The area of this unit, like that of the Equisetum unit, was part of the undisturbed forest in 1987 (Figs. 2 and 3). In 1997, it was located adjacent to the headwall, in an area where the slope was quite steep $\left(30^{\circ}\right)$ with no apparent vegetation islands on or around it. Polygonum alaskanum was the visually dominant species because of its size, but 
TABLE 1. Vascular species composition of thaw-slump vegetation units in 1997 and of the units found in 1987 by Burn and Friele (1989). Values given are from the Braun-Blanquet cover abundance scale. ${ }^{1}$

\begin{tabular}{|c|c|c|c|c|c|c|c|c|c|c|c|}
\hline \multirow[b]{2}{*}{ Unit $^{2}$} & \multicolumn{5}{|c|}{1987 Units } & \multicolumn{6}{|c|}{1997 Units } \\
\hline & 2 & 3 & 4 & 5 & 6 & 1 & 2 & 3 & 4 & 5 & 6 \\
\hline Age of surface (yr) & $1-2$ & $2-5$ & $6-9$ & $6-15$ & $12-15$ & $4-7$ & $5-10$ & $8-13$ & $13-25$ & $20-31$ & $22-25$ \\
\hline Sampling plot size $\left(\mathrm{m}^{2}\right)$ & 1 & 128 & 256 & 64 & 16 & 2 & 32 & 32 & 64 & 64 & 32 \\
\hline \multicolumn{12}{|l|}{ i. Herb Cover } \\
\hline 1. Senecio congestus ${ }^{3}$ & 4 & 3 & $\mathrm{r}$ & $\mathrm{r}$ & & & & & & $\mathrm{r}$ & \\
\hline 2. Chenopodium capitatum & & $\mathrm{r}$ & & & & & & & & & \\
\hline 3. Descurainia richardsonii & & + & & & & & & & & & \\
\hline 4. Senecio lugens & & $\mathrm{r}$ & & & & & & & & & \\
\hline 5. Epilobium palustre & 1 & 1 & 1 & + & & & & $\mathrm{r}$ & & & \\
\hline 6. Polygonum alaskanum & & $\mathrm{r}$ & $\mathrm{r}$ & $\mathrm{r}$ & & & 2 & & & & \\
\hline 7. Stellaria longifolia & & $\mathrm{r}$ & $\mathrm{r}$ & & $\mathrm{r}$ & & $\mathrm{r}$ & & & & \\
\hline 8. Equisetum arvense & & 3 & 4 & 4 & 2 & 3 & 1 & 4 & 3 & 3 & 1 \\
\hline 9. Cinna latifolia & & 1 & 3 & 1 & + & $\mathrm{r}$ & 3 & 3 & + & + & $\mathrm{r}$ \\
\hline 10. Erysimum cheiranthoides & & & & & & & & $\mathrm{r}$ & & & \\
\hline 11. Geum aleppicum & & & & & & & & $\mathrm{r}$ & & & \\
\hline 12. Epilobium angustifolium & & + & 2 & 1 & + & $\mathrm{r}$ & 2 & 2 & + & + & + \\
\hline 13. Hedysarum alpinum & & & & & & + & & & 1 & $\mathrm{r}$ & + \\
\hline 14. Hedysarum boreale & & + & + & 1 & 1 & & & & & & \\
\hline 15. Arnica alpina & & & $\mathrm{r}$ & + & + & & & & & & $\mathrm{r}$ \\
\hline 16. Equisetum fluviatile & & & & & & & & $\mathrm{r}$ & & & \\
\hline 17. Equisetum scirpoides & & & $\mathrm{r}$ & & & & & & & & \\
\hline 18. Hordeum jubatum & & & $\mathrm{r}$ & + & & & & $\mathrm{r}$ & & & \\
\hline 19. Habenaria hyperborea & & & & + & $\mathrm{r}$ & & & & & & \\
\hline 20. Gentianella propinqua & & & & $\mathrm{r}$ & + & & & & & & \\
\hline 21. Parnassia palustris & & & & + & 1 & $\mathrm{r}$ & & & 2 & + & + \\
\hline 22. Astragalus alpinus & & & & & & & & & & & $\mathrm{r}$ \\
\hline 23. Astragalus agrestis & & & & $\mathrm{r}$ & $\mathrm{r}$ & & & & & & \\
\hline 24. Achillea millefolium & & & & $\mathrm{r}$ & $\mathrm{r}$ & & $\mathrm{r}$ & & & & \\
\hline 25. Mertensia paniculata & & & & & & & + & $\mathrm{r}$ & & $\mathrm{r}$ & + \\
\hline 26. Erigeron acris & & & & $\mathrm{r}$ & + & & $\mathrm{r}$ & $\mathrm{r}$ & $\mathrm{r}$ & & \\
\hline 27. Spiranthes romanzoffiana & & & & & & $\mathrm{r}$ & & & + & $\mathrm{r}$ & $\mathrm{r}$ \\
\hline 28. Corallorhiza trifida & & & & & $\mathrm{r}$ & & & & & & $\mathrm{r}$ \\
\hline 29. Amerorchis rotundifolia & & & & & & & & & & & $\mathrm{r}$ \\
\hline 30. Aster commutatus & & & & & $\mathrm{r}$ & & & & & & \\
\hline 31. Ranunculus orthorhyncus & & & & & + & & & & & & \\
\hline 32. Rubus arcticus & & & & & $\mathrm{r}$ & & & & & & \\
\hline \multicolumn{12}{|l|}{ ii. Sub-shrubs } \\
\hline 33. Ribes glandulosum & & & $\mathrm{r}$ & & & & & & & & \\
\hline 34. Rubus idaeus & & + & 2 & $\mathrm{r}$ & $\mathrm{r}$ & & + & $\mathrm{r}$ & $\mathrm{r}$ & $\mathrm{r}$ & \\
\hline 35. Ribes hudsonianum & & + & 2 & + & + & $\mathrm{r}$ & $\mathrm{r}$ & $\mathrm{r}$ & $\mathrm{r}$ & $\mathrm{r}$ & $\mathrm{r}$ \\
\hline 36. Shepherdia canadensis & & $\mathrm{r}$ & + & + & + & & & & + & $\mathrm{r}$ & 2 \\
\hline 37. Vaccinium vitis-idaea & & + & + & + & + & & & & $\mathrm{r}$ & & 1 \\
\hline 38. Rosa acicularis & & + & 1 & 1 & 1 & & 1 & $\mathrm{r}$ & $\mathrm{r}$ & + & $\mathrm{r}$ \\
\hline 39. Ledum decumbens & & + & 1 & + & $\mathrm{r}$ & & & & $\mathrm{r}$ & $\mathrm{r}$ & $\mathrm{r}$ \\
\hline 40. Linnaea borealis & & + & + & + & + & & & & & & \\
\hline 41. Arctostaphylos uva-ursi & & & & & & & & & & & $\mathrm{r}$ \\
\hline 42. Arctostaphylos rubra & & $\mathrm{r}$ & $\mathrm{r}$ & + & $\mathrm{r}$ & & & & & & + \\
\hline 43. Pyrola asarifolia & & $\mathrm{r}$ & $\mathrm{r}$ & + & $\mathrm{r}$ & & & & & & \\
\hline 44. Viburnum edule & & & $\mathrm{r}$ & $\mathrm{r}$ & & & & & & & \\
\hline 45. Potentilla fruticosa & & & & & + & & & & & & + \\
\hline 46. Geocaulon lividum & & & + & & & & & & & & \\
\hline 47. Empetrum nigrum & & & & & & & & & & & + \\
\hline \multicolumn{12}{|l|}{ iii. Tree saplings and shrubs } \\
\hline 48. Salix lasiandra & & + & $\mathrm{r}$ & $\mathrm{r}$ & & & & $\mathrm{r}$ & $\mathrm{r}$ & $\mathrm{r}$ & $\mathrm{r}$ \\
\hline 49. Salix interior & & + & $\mathrm{r}$ & $\mathrm{r}$ & $\mathrm{r}$ & + & & $\mathrm{r}$ & + & $\mathrm{r}$ & \\
\hline 50. Salix alaxensis & & $\mathrm{r}$ & + & + & + & $\mathrm{r}$ & $\mathrm{r}$ & $\mathrm{r}$ & & $\mathrm{r}$ & $\mathrm{r}$ \\
\hline 51. Salix novae-angliae & & $\mathrm{r}$ & 2 & 1 & 1 & $\mathrm{r}$ & & $\mathrm{r}$ & $\mathrm{r}$ & + & + \\
\hline 52. Salix arbusculoides & & + & 3 & 2 & 1 & $\mathrm{r}$ & $\mathrm{r}$ & $\mathrm{r}$ & $\mathrm{r}$ & 1 & 1 \\
\hline 53. Salix glauca & $\mathrm{r}$ & + & 2 & 2 & 1 & & + & 2 & 2 & + & $\mathrm{r}$ \\
\hline 54. Salix bebbiana & & & & & & $\mathrm{r}$ & $\mathrm{r}$ & + & + & + & \\
\hline 55. Salix monticola & & & & & & & $\mathrm{r}$ & $\mathrm{r}$ & & & \\
\hline 56. Populus balsamifera & & & $\mathrm{r}$ & 1 & + & & & & + & $\mathrm{r}$ & $\mathrm{r}$ \\
\hline 57. Populus tremuloides & & & & & & & & & $\mathrm{r}$ & & \\
\hline 58. Betula papyrifera & & $\mathrm{r}$ & 2 & + & 1 & $\mathrm{r}$ & 2 & $\mathrm{r}$ & + & $\mathrm{r}$ & 1 \\
\hline 59. Picea glauca & & $\mathrm{r}$ & 1 & $\mathrm{r}$ & 2 & & $\mathrm{r}$ & & 1 & 1 & 1 \\
\hline
\end{tabular}


TABLE 1. Vascular species composition of thaw-slump vegetation units in 1997 and of the units found in 1987 by Burn and Friele (1989). Values given are from the Braun-Blanquet cover abundance scale. ${ }^{1}-$ continued:

\begin{tabular}{|c|c|c|c|c|c|c|c|c|c|c|c|}
\hline \multirow{4}{*}{$\begin{array}{l}\text { Unit }^{2} \\
\text { Age of surface }(y r) \\
\text { Sampling plot size }\left(\mathrm{m}^{2}\right)\end{array}$} & \multicolumn{5}{|c|}{1987 Units } & \multicolumn{6}{|c|}{1997 Units } \\
\hline & 2 & 3 & 4 & 5 & 6 & 1 & 2 & 3 & 4 & 5 & 6 \\
\hline & $1-2$ & $2-5$ & $6-9$ & $6-15$ & $12-15$ & $4-7$ & $5-10$ & $8-13$ & $13-25$ & $20-31$ & $22-25$ \\
\hline & 1 & 128 & 256 & 64 & 16 & 2 & 32 & 32 & 64 & 64 & 32 \\
\hline \multicolumn{12}{|l|}{ iv. Trees } \\
\hline 60. Picea glauca & & & & & $\mathrm{r}$ & & & & & $\mathrm{r}$ & 2 \\
\hline 61. Betula papyrifera & & & & & + & & & & & $\mathrm{r}$ & $\mathrm{r}$ \\
\hline
\end{tabular}

${ }^{1}$ Braun-Blanquet cover abundance scale: $5=>75 \% ; 4=50-75 \% ; 3=25-50 \% ; 2=5-25 \% ; 1$ numerous, but $<5 \%$ cover; $+=$ few, small cover; $r=$ solitary, small cover.

${ }^{2}$ Unit names: (1987) 2 -Funaria; 3 - Senecio;4-Equisetum/Salix; 5 -Equisetum; 6-Salix/Betula; (1997) 1 -Equisetum;2 - Polygonum; 3 - Equisetum/Salix; 4 - Salix; 5 - Salix/Picea; 6 - Salix/Betula.

${ }^{3}$ Identification number indicates species reference in Figures 4 and 5.

Cinna latifolia covered more ground. The presence of both species indicated a drier environment that supported the relatively abundant Betula saplings.

\section{Equisetum/Salix (Unit 3: 8-13 Years Old)}

In 1987 , the area occupied by this unit was encompassed by the Funaria unit and part of the Equisetum/Salix unit. In 1997, the unit appeared more mature than the Equisetum unit (\#1): the Salix were largely shrubs (1.5 m tall), there were more sub-shrubs, and Cinna latifolia was abundant, indicating drying of the area in the Funaria unit since 1987.

\section{Salix (Unit 4: 13-25 Years Old)}

This unit included areas that had been part of the Equisetum/Salix and Equisetum units in 1987. The effects of the cessation of slumping were evident in the disappearance of marshes that had covered a large portion of this unit in 1987. The abundance of Equisetum (Table 1) indicated that the environment had remained moist, while the Salix shrubs shaded the ground.

\section{Salix/Picea (Unit 5: 21-32 Years Old)}

This area is the oldest part of the slump floor and was mapped in 1987 as part of the Equisetum unit. Proximity to the river has kept parts of it moist. In 1997, it supported a variety of Salix species and contained mature Picea glauca. The presence of Shepherdia canadensis and Vaccinium vitisidaea in 1997 indicated progressive reestablishment of ground vegetation characteristic of the surrounding forest.

\section{Salix/Betula (Unit 6: 22-25 years old)}

This unit was mapped in the same terrain in 1987. The site is separated from the main foot slope by a ridge of dry ground that may have served to protect vegetation islands from being moved away by mud flows, hence allowing them to reestablish. This protection, in combination with proximity to the undisturbed forest, probably accelerated the reestablishment of the forest vegetation. Floristically, this unit most closely resembled the undisturbed forest. Picea glauca was more abundant in this unit than in any other. The abundance of Shepherdia canadensis and Vaccinium vitis-idaea had increased since 1987, and that of Equisetum arvense had decreased. Changes in cover of these three species in particular indicated evolution towards the flora of the surrounding forest.

\section{Ordination}

Figures 4 and 5 present ordination diagrams, based on detrended correspondence analysis of the species abundances in Table 1 and data for the stabilized slump and undisturbed forest from 1987 (Burn and Friele, 1989, Table 3). The first two axes identified by the analyses and displayed on the diagrams account for the majority of variation in the data, $72 \%$ in 1987 and $68 \%$ in 1997 . For the 1987 data, the horizontal axis is associated with variation in the herb population, while the vertical axis is associated with variation in sub-shrub and shrub/sapling composition. In addition, the horizontal axis discriminates between the units on the basis of age, indicating the successional sequence. Units 7 (stabilized slump) and 8 (undisturbed forest) are proximal on Figure 4, in agreement with the conclusion reached by Burn and Friele (1989) that the vegetation community in the stabilized slump is similar to that of the surrounding mature forest.

Figure 4 indicates that in 1987 the vegetation communities in units 2, 3 and 4 were discriminated by the herb flora, while separation of the Equisetum/Salix, Equisetum and Salix/Betula units (4, 5, and 6) was made on the basis of sub-shrubs and shrubs. The separation of units 4,5 , and 6 from units 7 and 8 is associated with the recognition of trees in the latter units. For 1987, the horizontal axis also separates sites by distance from the headwall, the principal source of moisture in the thaw slump, along a gradient in soil moisture content. 


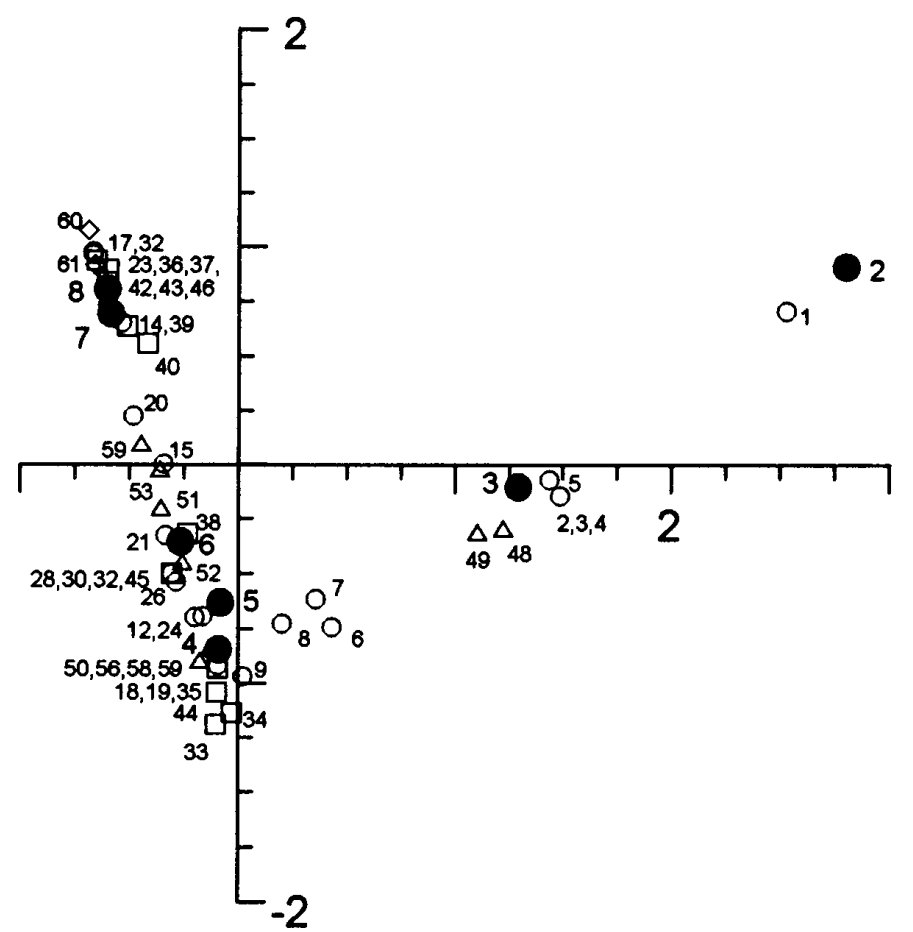

FIG. 4. Ordination (DCA) diagram for vegetation abundances measured in 1987. The species are numbered as in Table 1. Herbs are plotted with open circles $(\bigcirc)$, sub-shrubs with squares $(\square)$, saplings and shrubs with triangles $(\triangle)$, trees with diamonds $(\diamond)$, and the vegetation units by filled circles $(\bullet)$. The horizontal and vertical axes account for $43 \%$ and $29 \%$ of the variation in the data set respectively.

Figure 5 indicates a different pattern for analysis of 1997 data. The three principal differences from Figure 4 are the divergence of the Polygonum unit (2) from the other units; the placement of unit 6 in a cluster with units 7 and 8 ; and the fact that neither axis is associated with particular growth forms. The separation of the Polygonum unit from the others indicates alteration of succession due to edaphic conditions, while the position of unit 6 with units 7 and 8 indicates the appearance of the vegetation community of the undisturbed forest in the thaw slump 25 years after disturbance. While the horizontal axis in Figure 5 discriminates sites on the basis of age, the vertical axis is inversely associated with the moisture content of the substrate.

Table 2 summarizes the diversity of the vegetation communities in the thaw slump. There has been little change in the total number of species found in the slump (46 in 1987; 43 in 1997), but this statistic masks the decline in variety of herbs and sub-shrubs in most units. For units of similar age, i.e., Senecio (\#3) of 1987 and Equisetum (\#1) of 1997, Equisetum (\#5) of 1987 and Equisetum/Salix (\#3) of 1997, the number of herb species declined by about $40 \%$ over the 10 years between surveys and the number of sub-shrubs by a greater fraction. The variety of shrubs in the separate units has increased slightly. Overall, the number of herb and sub-shrub species recorded dropped from 36 to 31, while the number of tree and shrub species increased from 9 to 12 .

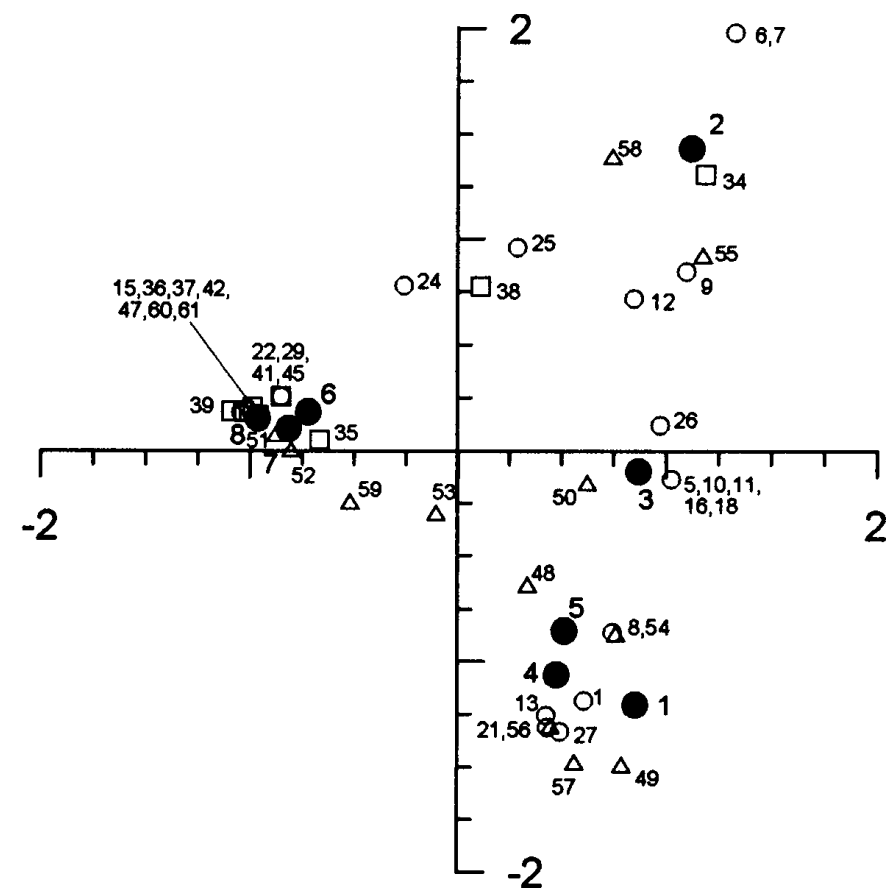

FIG. 5. Ordination (DCA) diagram for vegetation abundances collected in 1997. The species are numbered as in Table 1. Herbs are plotted with open circles $(\bigcirc)$, sub-shrubs with squares $(\square)$, shrubs with triangles $(\triangle)$, trees with diamonds $(\diamond)$, and the vegetation units by filled circles $(\bullet)$. The horizontal and vertical axes account for $39 \%$ and $29 \%$ of the variation in the data set respectively.

\section{DISCUSSION}

Space-for-time substitution, the ergodic hypothesis, is commonly used in studies of plant succession because of the difficulty in obtaining long-term data from fixed plots (Pickett, 1989). Inferring successional development from a chronosequence assumes that the study area is spatially homogeneous and that the environment has been stable throughout the time period of interest. In general, chronosequence-based studies of succession have not provided empirical support for these assumptions (e.g., Cooper, 1923; Crocker and Major, 1955). Indeed, plants respond individualistically to climatic and other environmental factors that vary over both space and time, such as the availability of species propagules, so that the key assumptions of chronosequences are rarely, if ever, met (Gleason, 1927; Prach, 1994; Fastie, 1995; Mann et al., 1995; Klinger and Short, 1996). Field and laboratory experiments by Chapin et al. (1994) and Fastie (1995) showed that the sequence of plant communities described by Cooper (1923) and Crocker and Major (1955) from sites of various ages at Glacier Bay, Alaska, did not represent the temporal sequence of vegetation change at each site. Comparison of Figures 4 and 5 also indicates that the chronosequence identified in 1987 only partially accounts for the evolution of vegetation communities in the thaw slump.

While some of the units closest to the headwall were still moist environments, dominated by Salix and Equisetum, as in 1987, a new unit dominated by Polygonum 
TABLE 2. Number of vascular plant species identified in each thaw-slump vegetation unit in 1987 and 1997.

\begin{tabular}{|c|c|c|c|c|c|c|c|c|c|c|c|c|c|}
\hline \multirow[b]{2}{*}{$\begin{array}{l}\text { Unit }^{1} \\
\text { Age }(y r)\end{array}$} & \multicolumn{6}{|c|}{1987} & \multicolumn{7}{|c|}{1997} \\
\hline & $\begin{array}{c}2 \\
1-2\end{array}$ & $\begin{array}{c}3 \\
2-5\end{array}$ & $\begin{array}{c}4 \\
6-9\end{array}$ & $\begin{array}{c}5 \\
6-15\end{array}$ & $\begin{array}{c}6 \\
12-15\end{array}$ & Total & $\begin{array}{c}1 \\
4-7\end{array}$ & $\begin{array}{c}2 \\
5-10\end{array}$ & $\begin{array}{c}3 \\
8-13\end{array}$ & $\begin{array}{c}4 \\
13-25\end{array}$ & $\begin{array}{c}5 \\
20-31\end{array}$ & $\begin{array}{c}6 \\
22-25\end{array}$ & Total \\
\hline Herbs & 2 & 11 & 11 & 15 & 16 & 24 & 6 & 8 & 10 & 7 & 8 & 11 & 21 \\
\hline Sub-shrubs & - & 9 & 12 & 10 & 10 & 13 & 1 & 3 & 3 & 6 & 5 & 9 & 10 \\
\hline Tree saplings and shrubs & 1 & 8 & 9 & 9 & 8 & 9 & 6 & 7 & 9 & 10 & 10 & 8 & 12 \\
\hline Trees & - & - & - & - & 2 & 2 & - & - & - & - & 2 & 2 & 2 \\
\hline Total & 3 & 28 & 32 & 34 & 34 & 46 & 13 & 18 & 22 & 23 & 23 & 28 & 43 \\
\hline
\end{tabular}

${ }^{1}$ Unit names: 1987: 2 - Funaria; 3 - Senecio; 4 -Equisetum/Salix; 5 -Equisetum; 6 - Salix/Betula. 1997: 1 - Equisetum; 2 - Polygonum; 3 - Equisetum/Salix; 4 - Salix; 5 - Salix/Picea; 6 - Salix/Betula.

alaskanum was found in 1997. The Polygonum unit was located adjacent to the headwall, in an area where the slope was steep $\left(30^{\circ}\right)$ with no apparent vegetation islands on or around it. This unit, in combination with an undisturbed Betula grove beyond the headwall, indicative of dry soil, suggested that the cessation of slumping in this area was due to exhaustion of ground ice, rather than to insulation of the headwall by fallen debris. These relatively dry conditions caused the difference in vegetation from the Equisetum unit, which is of similar age. In the main part of the foot slope, surface drying was characterized by a decrease in the abundance of Senecio congestus and Epilobium palustre, both species that prefer moist, open environments (Porsild and Cody, 1980).

Burn and Friele (1989) hypothesized that, with time, there would be redistribution in abundance of species towards those found in more mature communities. The more widespread appearance of Parnassia palustris, Erigeron acris, and Spiranthes romanzoffiana and the classification of unit 6 with units 7 and 8 on Figure 5 follow this suggestion. However, other herbs present in older units in 1987 were not observed in 1997 (Table 1), and the herbs and sub-shrubs that were most abundant in 1997, i.e., Equisetum arvense, Cinna latifolia, and Epilobium angustifolium, had also been prominent in 1987 (Table 1). Older units farther from the headwall all registered an increase in abundance of Picea and Salix in 1997.

Burn and Friele (1989) recognized that soil moisture conditions could alter the vegetation succession locally. The present study shows that drier soils near the headwall have resulted in communities different from the successional sequence described in 1987, e.g., the Polygonum unit.

In summary, it appears that the sequence of species by which vegetation developed in the slump between 1987 and 1997 was determined by the availability of species propagules and the environmental conditions encountered by these propagules (cf. Gleason, 1927; Fastie, 1995). In particular, cessation of the meltwater supply influenced species establishment and development. A Betula-dominated forest will likely establish itself on the foot slope, probably within 35-50 years, and will eventually be replaced by a Picea-dominated forest like that existing in much of the area surrounding the slump. In 1997, Betula was sufficiently abundant to be recognized as a dominant species in the Salix/Betula unit. It remains to be seen, in 2007, whether the present chronosequence will guide further vegetation development, or whether continuing changes in environmental conditions and species availability will cause further alteration to the successional communities.

\section{ACKNOWLEDGEMENTS}

The fieldwork was supported by the Natural Sciences and Engineering Research Council of Canada, with supplementary support from the Northern Scientific Training Program of the Department of Indian Affairs and Northern Development, the Royal Canadian Geographical Society, and the Northern Research Institute, Yukon College. The hospitality and friendship of the community of Mayo, especially Michel Menelon, Jim and Shann Carmichael, the J.V. Clark School, and the Community Learning Centre, Yukon College, are acknowledged with gratitude. Able field assistance from Erica Kotler and Ross Cooper contributed to the survey. The cartography is by Christine Earl. Many helpful suggestions and valuable comments were provided by the referees.

\section{REFERENCES}

BENZÉCRI, J-P. 1992. Correspondence analysis handbook. New York: Marcel Dekker. 665 p.

BILLINGS, W.D., and PETERSON, K.M. 1980. Vegetational change and ice-wedge polygons through the thaw-lake cycle in arctic Alaska. Arctic and Alpine Research 12:413-432.

BOSTOCK, H.S. 1966. Notes on glaciation in central Yukon Territory. Geological Survey of Canada Paper 65-36. 18 p.

BURN, C.R. 1998. Field investigations of permafrost and climatic change in northwest North America. In: Lewkowicz, A.G., and Allard, M., eds. Proceedings, Seventh International Conference 
on Permafrost, 23-26 June 1998, Yellowknife, N.W.T. Nordicana, Quebec. 107-120.

BURN, C.R., and FRIELE, P.A. 1989. Geomorphology, vegetation succession, soil characteristics and permafrost in retrogressive thaw slumps near Mayo, Yukon Territory. Arctic 42:31-40.

BURN, C.R., and LEWKOWICZ, A.G. 1990. Retrogressive thaw slumps. The Canadian Geographer 34:273-276.

BURN, C.R., and SMITH, M.W. 1990. Development of thermokarst lakes during the Holocene at sites near Mayo, Yukon Territory. Permafrost and Periglacial Processes 1:161-176.

CARGILL, S.M., and CHAPIN, F.S., III. 1987. Application of successional theory to tundra restoration: A review. Arctic and Alpine Research 19:366-372.

CHAPIN, F.S., III, WALKER, L.R., FASTIE, C.L., and SHARMAN, L.C. 1994. Mechanisms of primary succession following deglaciation at Glacier Bay, Alaska. Ecological Monographs 64:149-175.

CODY, W.J. 1996. Flora of the Yukon Territory. Ottawa: NRC Research Press. 643 p.

COOPER, W.S. 1923. The recent ecological history of Glacier Bay, Alaska: II. The present vegetation cycle. Ecology 4:223-246.

CROCKER, R.L., and MAJOR, J. 1955. Soil development in relation to vegetation and surface age at Glacier Bay, Alaska. Journal of Ecology 43:427-448.

ENVIRONMENT CANADA. 1993. Canadian climate normals, 1961-90, Yukon and Northwest Territories. Ottawa: Environment Canada, Canadian Climate Program.

FASTIE, C.L. 1995. Causes and ecosystem consequences of multiple pathways of primary succession at Glacier Bay, Alaska. Ecology 76:1899-1916.

GILL, D. 1973. Floristics of a plant succession sequence in the Mackenzie delta, Northwest Territories. Polarforschung 43: $55-65$.

GLEASON, H.A. 1927. Further views on the succession concept. Ecology 8:299-326.

HEGINBOTTOM, J.A., DUBREUIL, M.A., and HARKER, P.A. 1995. Canada-Permafrost. In: National Atlas of Canada, 5th ed. National Atlas Information Service. Ottawa: Natural Resources Canada. Plate 2.1.

HUGHES, O.L. 1983. Surficial geology and geomorphology, Janet Lake, Yukon Territory. Geological Survey of Canada Map 41982.

KLINGER, L.F., and SHORT, S.K. 1996. Succession in the Hudson Bay Lowland, northern Ontario, Canada. Arctic and Alpine Research 28:172-183.
LAMBERT, J.D.H. 1972. Plant succession on tundra mudflows: Preliminary observations. Arctic 25:99-106.

LEVERINGTON, D. 1995. A field survey of late-summer depths to frozen ground at two study areas near Mayo, Yukon Territory, Canada. Permafrost and Periglacial Processes 6:373-379.

MANN, D.H., FASTIE, C.L., ROWLAND, E.L., and BIGELOW, N.H. 1995. Spruce succession, disturbance, and geomorphology on the Tanana River Flood plain, Alaska. Ecoscience 2: $184-199$.

MUELLER-DOMBOIS, D., and ELLENBERG, H. 1974. Aims and methods of vegetation ecology. New York: Wiley. 547 p.

OVENDEN, L. 1986. Vegetation colonizing the bed of a recently drained thermokarst lake (Illisarvik), Northwest Territories. Canadian Journal of Botany 64:2688-2692.

PICKETT, S.T.A. 1989. Space-for-time substitution as an alternative for long-term studies. In: Likens, G.E., ed. Long-term studies in ecology: Approaches and alternatives. New York: SpringerVerlag. 110-135.

PORSILD, A.E., and CODY, W.J. 1980. Vascular plants of continental Northwest Territories, Canada. Ottawa: National Museums of Canada. 667 p.

PRACH, K. 1994. Vegetation succession on river gravel bars across the northwestern Himalayas, India. Arctic and Alpine Research 26:349-353.

SMITH, C.A.S., BURN, C.R., TARNOCAI, C., and SPROULE, B. 1998. Air and soil temperature relations along an ecological transect through the permafrost zones of northwestern Canada. In: Lewkowicz, A.G., and Allard, M., eds. Proceedings, Seventh International Conference on Permafrost, 23-26 June 1998, Yellowknife, N.W.T. Nordicana, Quebec. 1009-1016.

TER BRAAK, C.J.F. 1995. Ordination. In: Jongman, R.H.G., Ter Braak, C.J.F., and van Tongeren, O.F.R., eds. Data analysis in community and landscape ecology. Cambridge: Cambridge University Press. 91-173.

TER BRAAK, C.J.F., and PRENTICE, I.C. 1988. A theory of gradient analysis. Advances in Ecological Research 18: $271-317$.

VIERECK, L.A. 1970. Forest succession and soil development adjacent to the Chena River in interior Alaska. Arctic and Alpine Research 3:1-26.

WILSON, C.E., HUTCHISON, T.C., and BURN, C.R. 1996. Natural revegetation of placer mine tailings near Mayo, central Yukon. In: LeBarge, W.P., ed. Yukon Quaternary Geology Volume 1. Whitehorse: Northern Affairs Program. 47-62. 